\title{
The Vicious Cycle of Palestinian Workers in Israel Settlements
}

Asem Khalil

CARIM Analytic and Synthetic Notes 2009/17 Legal Module

Cooperation project on the social integration of immigrants, migration, and the movement of persons 


\author{
CARIM \\ Euro-Mediterranean Consortium \\ for Applied Research on International Migration
}

\title{
Analytic and Synthetic Notes - Legal Module \\ CARIM-AS 2009/17
}

\author{
Asem Khalil \\ Faculty of Law and Public Administration, Birzeit University
}

The Vicious Cycle of Palestinian Workers in Israeli Settlements 
This text may be downloaded only for personal research purposes. Any additional reproduction for other purposes, whether in hard copies or electronically, requires the consent of the Robert Schuman Centre for Advanced Studies.

Requests should be addressed to forinfo@eui.eu

If cited or quoted, reference should be made as follows:

[Full name of the author(s)], [title], CARIM AS [series number], Robert Schuman Centre for Advanced Studies, San Domenico di Fiesole (FI): European University Institute, [year of publication].

THE VIEWS EXPRESSED IN THIS PUBLICATION CANNOT IN ANY CIRCUMSTANCES BE REGARDED AS THE OFFICIAL POSITION OF THE EUROPEAN UNION

\author{
European University Institute \\ Badia Fiesolana \\ I - 50014 San Domenico di Fiesole (FI) \\ Italy \\ http://www.eui.eu/RSCAS/Publications/ \\ http://www.carim.org/Publications/ \\ http://cadmus.eui.eu
}




\section{CARIM}

The Euro-Mediterranean Consortium for Applied Research on International Migration (CARIM) was created in February 2004 and has been financed by the European Commission. Until January 2007, it referred to part $\mathrm{C}$ - "cooperation related to the social integration of immigrants issue, migration and free circulation of persons" of the MEDA programme, i.e. the main financial instrument of the European Union to establish the Euro-Mediterranean Partnership. Since February 2007, CARIM has been funded as part of the AENEAS programme for technical and financial assistance to third countries in the areas of migration and asylum. The latter programme establishes a link between the external objectives of the European Union's migration policy and its development policy. AENEAS aims at providing third countries with the assistance necessary to achieve, at different levels, a better management of migrant flows.

Within this framework, CARIM aims, in an academic perspective, to observe, analyse, and predict migration in the North African and the Eastern Mediterranean Region (hereafter Region).

CARIM is composed of a coordinating unit established at the Robert Schuman Centre for Advanced Studies (RSCAS) of the European University Institute (EUI, Florence), and a network of scientific correspondents based in the 12 countries observed by CARIM: Algeria, Egypt, Israel, Jordan, Lebanon, Morocco, Palestine, Syria, Tunisia, Turkey and, since February 2007, also Libya and Mauritania. All are studied as origin, transit and immigration countries. External experts from the European Union and countries of the Region also contribute to CARIM activities.

The CARIM carries out the following activities:

- Mediterranean migration database;

- Research and publications;

- Meetings of academics;

- Meetings between experts and policy makers;

- Early warning system.

The activities of CARIM cover three aspects of international migration in the Region: economic and demographic, legal, and socio-political.

Results of the above activities are made available for public consultation through the website of the project: www.carim.org

For more information:

Euro-Mediterranean Consortium for Applied Research on International Migration

Robert Schuman Centre for Advanced Studies (EUI)

Convento

Via delle Fontanelle 19

50014 San Domenico di Fiesole

Italy

Tel: +390554685878

Fax: + 390554685762

Email: carim@eui.eu

\section{Robert Schuman Centre for Advanced Studies}

http://www.eui.eu/RSCAS/ 


\begin{abstract}
This paper is interested in presenting the status of rights of Palestinians working in Israeli settlements. Available reports suggest that these are subjected to discrimination, exploitation and human-rights violations both in terms of employment conditions and safety measures.

In October 2007, the Israeli High Court ruled unanimously that Israeli labor laws applied equally to Israeli employers and their Palestinian West Bank workers. The decision signs a breakthrough for Palestinian workers, but raises questions with regards to the ruling's enforcement and implications, given that Israeli settlements are illegal under international law.

This paper argues that granting equal rights without discrimination based on nationality is an obligation for all states. Accordingly, it is inconceivable that we re-interpret international humanitarian law so as to allow the discrimination of local populations and the application of dual legal systems. Such a reinterpretation would lead to the system that was historically applied in several countries, i.e. "colonization," and/or "apartheid," and to the system that is currently applied in Israeli settlements.
\end{abstract}

\title{
Résumé
}

Cette contribution rend compte de la nature des droits reconnus aux travailleurs palestiniens employés dans les colonies israéliennes en Cisjordanie. Les rapports dont on dispose sur le sujet montrent qu'ils font l'objet de discriminations, d'exploitation et de violation de leurs droits fondamentaux que ce soit eu égard à leurs conditions de travail ou aux conditions de sécurité sur leur lieu de travail.

En octobre 2007, la Cour suprême israélienne a rendu, à l'unanimité de ses membres, un arrêt qui tranche la question de la loi applicable aux relations de travail entre les employeurs israéliens et leurs employés palestiniens dans les colonies israéliennes en Cisjordanie : la loi israélienne doit s'appliquer. Cette décision est une avancée pour la condition des travailleurs palestiniens mais soulève de nombreuses questions quant à son application ou à ses implications, étant donné que les colonies israéliennes sont contraires au droit international public.

Enfin, cet article avance que, en vertu du principe de reconnaissance de droits égaux sans distinction de nationalité qui s'impose à tout Etat, il est inconcevable que le droit international humanitaire soit interprété de telle sorte qu'il laisse persister une situation de discrimination des populations locales et l'application de deux systèmes juridiques différents. Dans le contexte israélopalestinien, cela reviendrait à avaliser un système d' « apartheid » ou " colonial » que l'histoire a déjà connu dans d'autres pays et qui se perpétue dans les colonies israéliennes. 


\section{Introduction}

The criteria that dictate the selection of Palestinian workers for Israeli settlements are similar to the criteria feudal lords employed when they would chose the strongest workers (Abu Yusuf 06/12/2008). The interesting thing about this process is that it involves, beside the employer and the worker, two other actors. First, a contractor, who is a Palestinian middleman, standing between the Israeli employer and the Palestinian workers. And, second, the Israeli Military administration which regulates work permits for Palestinians wishing to work inside Israeli settlements as it does for Palestinians wishing to work inside Israel.

The legal status of Israeli settlements and the way that Palestinians working inside these settlements are regulated, needs then, to be set out. The confusion regarding the system of law applicable there and the institutions responsible for enforcing that law is an important reason for the persistence of serious human-rights violations among Palestinian workers in Israeli settlements, built, illegally under international law, in the West Bank.

In October 2007 the Israeli Supreme Court (ISC) issued unanimously, with a nine judge panel, an important decision in which it concluded the debate on which law applies to Palestinians working in Israeli settlements, imposing Israeli law on both Israeli employers and Palestinian workers. The current author tends to be cautious with regards to the optimism that accompanied the adoption of such a decision on Palestinian workers inside Israeli settlements. The ISC rulings are often ignored by Israeli employers, and are not enforced by the Israeli Military administration or by public inspection offices.

This paper is interested in presenting the status of rights of Palestinians working in Israeli settlements. In fact, human-rights reports and academic research suggest that most of the workers employed in Israeli factories in settlements' industrial zones are "subjected to exploitation and human rights violation both in terms of employment conditions and safety measures” (Abu Yusuf 28/04/2008).

It is interesting to note that there has always been insufficient information concerning this topic. If available reports are mostly journalistic or the product of field research carried out by Israeli NGOs. The current author argues that the limited number of studies and the late appearance of this topic on the agenda of human-rights organizations, especially on the Palestinian side, ${ }^{1}$ does not necessarily reflect their lack of interest. It rather expresses the frustration of the workers themselves who feel helpless and, for fear of retaliation, choose silence over demanding their rights. The lack of data is made worse by the inaccessibility of settlements for academic research and human-rights reporting. ${ }^{2}$ It finally reflects the legal confusion that characterizes the system of law applicable in Israeli settlements.

\section{Recruiting Palestinian Workers}

An Israeli employer often has no direct contact with Palestinian workers. This is true of recruitment and even, in later stages, with the daily management of workers, and the payment of salaries. The 'dirty jobs,' as they are called in various reports (Ginat, 17/09/2006), are given to a Palestinian contractor. He serves as middlemen between workers and employers. Some large contractors even

\footnotetext{
${ }^{1}$ This does not mean that Palestinian society has no interest in this matter. On the contrary, Palestinian workers inside Israeli settlements and Israel are not marginalized in Palestinian society. They continue to be a major source of income for many Palestinian families in the West Bank (Kav LaOved, 11/01/2008).

${ }^{2}$ This explains why most references used in this paper are based on reports published by Kav LaOved. The research carried out by Kav LaOved was often obstructed. They even received several anonymous threatening phone calls (Korkus, 28/12/2008).
} 
employ sub-contractors. This makes it harder for workers to enter into direct contact with employers (Kav LaOved, 23/08/2008). However, the intervention of a middleman does not, as we will see, break the labor relationship between Palestinian workers and Israeli employer, which is a determinant factor in deciding the kind of law to be applied to this kind of work.

A contractor acts in three different capacities. He acts as an employment bureau. He may employ family members and the unemployed in his home village. With the kind of jobs available for Palestinians in Israeli settlements, his choices are often based on the physical characteristics of the workers (Abu Yusuf 06/12/2008). Some work permits are even registered in his name, and he provides worker transportation to the place of work in the settlement (Alinat, 03/01/2009). These extra services cost money for the Palestinian workers who are counting every penny. Palestinian contractors illegally charge workers around 1,000 Shekels for work permits (Kav LaOved, 03/12/2007; Alinat, 06/12/2008).

The contractor also acts as a work manager. He is responsible to the Israeli employer, for the workers' productivity. The Israeli employer often sets quotas. It is the task of the contractor to make this possible. To do so, a contractor will end up putting pressure on the workers themselves. The workers, willing to return the day after to work, need to comply with the contractor's instructions (Ginat, 17/09/2006). The job insecurity of Palestinian workers makes them easy prey. The contractor may even intervene with the employer to discourage workers from standing up for their rights (Alinat, 03/01/2009).

Finally, the contractor is often a means of transferring money from the employer to the workers (Alinat, 03/01/2009). The Palestinian worker often does not know, and does not dare ask, how much the Israeli employer has paid him for the work that the worker have done. Surveys carried out by field research suggest that Palestinian workers employed through a Palestinian contractor are paid less than those workers employed directly by the factory (Kav LaOved, 23/08/2008). Both groups, however, earn less than the Israeli minimum wage.

The important role of the contractor means that most workers see them as being 'above the law' (Alinat, 03/01/2009); indeed, they are sometimes described by Palestinian workers as a 'mafia,' because "they exploit workers with the consent of Israeli employers" (Kav LaOved, 03/12/2007). According to relevant surveys some workers are convinced that the labor contractor is their employer, and is responsible for employment conditions (Alinat, 03/01/2009). This perception does not reflect a simple misunderstanding. It was even used by the defense as an argument in a case filed in March 2008 to deny the existence of the employer-employee relationship (Kav LaOved, 23/08/2008).

Attorney Hashem Masrawa explains that a Court ruling of 1982 provides that there are ways of identifying who is the actual employer: "it is necessary to check who benefits from the work, who supplies the work tools, who is responsible for making decisions, and who supervises the work. In the majority of cases the firm on whose premises the workers are employed is responsible for them" (Alinat, 03/01/2009). Israeli Labor Courts have so far denied requests to consider Palestinian contractors as the actual employers of Palestinian workers in the Settlements (Alinat, 03/01/2009). It should finally be noted that the responsibility for compliance is with the employer on whose facilities a work accident occurred, even if the worker is employed through a contractor (Abu Yusuf, 06/12/2008).

\section{Permits for Work inside Israeli Settlements}

Unlike work permits for Israel which depends on quotas according to activity sectors, Israeli employers inside settlements in the West Bank can employ as many Palestinians as they want (Sinai, 04/07/2007). However, permits are often given only to workers over 35 years of age and most of them are employed in construction (Kav LaOved, 06/04/2008). Obtaining a work permit is not an easy task. Some workers therefore work 'black' with no contract or insurance (Korkus, 16/04/2007). Some reports talk about abusing workers' need for permits in order to coerce them into providing 
information and cooperating with Israeli security forces (Amro, 23/09/2008; Alinat, 06/12/2008). In some cases this happened when they went to renew the permit (Kav LaOved, 06/04/2008).

In order to receive a work permit, issued by the Israeli Military Administration, Palestinians must first have a magnetic card issued by police and Shin Bet (Shabak), the Israeli internal security services, after a thorough screening for possible security risks (Korkus, 16/04/2007). According to a Knesset study of 2007, some 120 thousand Palestinians in the West Bank and Gaza Strip hold such cards (Sinai, 04/07/2007). Obtaining a magnetic card, however, does not guarantee the granting of work permit (Alinat, 06/12/2008). In fact, the magnetic card is simply a 'smart' card because it can carry out a biometric identification. It began to be issued at the beginning of 2005. It bears a picture of a person's face and hands from both sides, an imprint of the eye and a fingerprint (Hass, 10/05/2007).

While the request for a magnetic card is made by workers themselves, work permits are requested by the employer on their behalf (Kav LaOved, 23/08/2008). A permit is extremely valuable for a Palestinian and forms an important trump card for employers and sometimes leads to blackmail. In this sense, the employer is in the stronger position. If the worker does not act according to his boss's instructions he loses his card and his job (Korkus, 16/04/2007). This is not the only reason why a permit is not renewed. Many Palestinian workers, indeed, are denied permit renewal for security reasons (Kav LaOved, 06/04/2008; Alinat, 06/12/2008). In this sense, the magnetic card is no longer proof of security reliability (Hass, 10/05/2007). The motives for granting or refusing the permit are not clear (Korkus, 16/04/2007). The decision appears to be arbitrary (Alinat, 06/12/2008). The same conclusion was reached by the Association for Civil Rights in Israel which petitioned the High Court against arbitrary categorization for security reasons (Hass, 10/05/2007).

Kav LaOved went further claiming, in a petition before the High Court of Justice on behalf of Omar Kumar, a Palestinian whose work permit and magnetic card were revoked for 'security reasons', that the decision to prevent the plaintiff from entering Israel for work purposes, abruptly cut off his livelihood. It claimed further that when the West Bank's military commander prevents the plaintiff's access to fair employment opportunities and resorts to 'methods of control' that prevent him from having a reasonable standard of living, it is the authority's duty to pay the plaintiff's sustenance. This requirement is consistent with Article 39 of the Geneva Convention that deals with the protection of people during war situations (Kav LaOevd, 09/05/2007).

\section{Work Conditions of Palestinian Workers in Israeli Settlements}

Based on research data collected by the Knesset Migrant Workers Committee, a recent Knesset study, published in July 2007, revealed that the 18 thousand Palestinian workers ${ }^{3}$ employed in West Bank settlements and factories, the industrial, agricultural, construction and services sectors, earn less than half the minimum wage stipulated by Israeli law. Many of them do not receive health insurance or are insufficiently insured for work-related accidents (Sinai, 04/07/2007). In some cases, employers even deducted from the worker's salary the days that he stayed at home to recover from an injury received at work (Abu Yusuf, 06/12/2008). Workers often do not receive paid holidays, vacation allowances, annual leave, sick leave or overtime pay (Kav LaOved, 23/08/2008; Alinat, 16/09/2008a; Amro, 23/09/2008).

In addition, data collected in the field shows that working environments in Israeli settlements are often life threatening for workers (Abu Yusuf, 06/12/2008), since they do not respect safety measures and standards (Kav LaOved, 23/08/2008). Protection measures are not respected in factories where

\footnotetext{
${ }^{3}$ The number may be higher since the number here refers to those who have permits from Civil Administration work permits. Certainly, local trade unions believe the number to be higher (Kav LaOved, 11/01/2008).
} 
workers are exposed to poisonous materials (Abu Yusuf, 06/12/2008). When protection equipment is available, it does not reach the required standards (Abu Yusuf, 08/06/2008). New workers do not receive training for heavy machines causing casualties through erroneous use of the machinery (Abu Yusuf, 08/06/2008; Abu Yusuf 06/12/2008).

According to a survey carried out by Kav LaOved in 2008 in 60 Israeli factories in the West Bank settlements, where 3000 Palestinian workers are employed, "97\% of the workers in those industry areas are directly exposed to dangers emerging from lack of implementation of basic work safety regulations. They also show that $59 \%$ of the workers are directly exposed to dangerous safety conditions, and are not equipped with adequate safety measures. $20 \%$ of the workers do receive some safety equipment, but this equipment does not meet minimal international standards. Furthermore, $17 \%$ of the workers receive safety equipment, but do not use it. Not a single factory supervises the use of safety equipment” (Alinat, 16/09/2008b). According to the same study, only 3\% of the Palestinian workers receive adequate and proper safety equipment and use them constantly during their work.

It is hard to prove that certain sicknesses are the direct consequence of work in factories in the settlements. However, when the majority of workers have the same symptoms and suffer from the same diseases, this is highly suggestive (Alinat, 16/09/2008b; Abu Yusuf, 06/12/2008). In fact, workers often suffer respiratory system illnesses, mainly asthma, hearing loss, spinal and limb illnesses, eye illnesses, nerve problems, lead poisoning and skin irritations (Abu Yusuf, 20/05/2008). It should be noted that certain work related illness show symptoms only after many years of exposure to a given materials (Abu Yusuf 06/12/2008). Workers dealing with dangerous materials are not sent to regular medical evaluations (Abu Yusuf, 20/05/2008). Sick workers have no chance of getting hired. They are simply fired and lose their difficult to replace income (Abu Yusuf, 06/12/2008).

It is worth mentioning that child labor is also common in Israeli settlements. According to a survey conducted in 2007, 1,900 child laborers work in settlements or in Israel and the demand for child workers is rising (Korkus, 28/12/2008). They are less expensive and move easily through check points. Children are easily manipulated and exploited. They often leave school because of the difficult economic situation, being the only source of income for their families. Contrary to conditions imposed by Israeli law and international standards, they suffer from hard and dangerous work with long hours. In all circumstances, Israeli law forbids work for children below the age of fourteen (Korkus, 28/12/2008), and work permits are issued by the civil administration for children over the age of fourteen (Ginat, 17/09/2006).

\section{Legal Rights Request Penalized}

In the case that workers demand improved conditions, they may lose their jobs because it is extremely easy to dismiss workers (Kav LaOved, 23/08/2008), and have them replaced by others. Palestinian workers are often threatened and intimidated to prevent them from demanding their legal rights; in other words, they are penalized when they go to the courts to obtain rights (Kav LaOved, 23/08/2008). In some cases Palestinians do not sue their employers because, as foreign residents in Israel, they have to deposit large sums of money to guarantee payment of court expenses, expenses which could reach 5,000 shekel before procedures have even started (Korkus, 16/04/2007).

Workers are often dismissed because of union activities; such dismissals are illegal under both international and domestic Israeli law (Kav LaOved, 02/07/2007). In certain cases dismissed workers are rehired following a court order applied for by Kav LaOved (Alinat, 16/09/2008a).

Sometimes employers use different techniques. They deceive workers by promising the amelioration of their work environment (Kav LaOved, 11/01/2008). Their wages are sometimes raised a bit, though they remain below the minimum wage. However, the Israeli "minimum wage law states 
that any agreement by an employee to accept less than the minimum wage is invalid" (Kav LaOved, 23/08/2008). In other cases, employers evade the 2007 ISC ruling by issuing pay slips with false attendance reports. The normal practice is to register fewer working days than those actually worked, so it appears that the minimum wage is being paid (Kav LaOved, 23/08/2008).

\section{Israeli Settlements: A Legal 'no-man's land'}

As we have seen, Palestinians working in Israeli settlements see their rights violated in various ways. Starting with the manner that they are recruited and the long process to obtain, and maintain permits for work in Israeli settlements and ending with the social and economic rights that they are subjected to and their working conditions. Despite the above risks, the competition for work in Israeli settlements remains high which makes Palestinian workers more vulnerable and allows them to be more easily manipulated; certain actions were undertaken by Palestinian workers, workers who were increasingly aware of their entitlements, but Israeli employers in the West Bank resisted their efforts.

The violation of the basic rights of Palestinian workers inside Israeli settlements persists despite the existence of progressive Israeli national legislation, the ISC ruling of October 2007, and international treaties to which Israel is party. The confusion concerning the system of law that governs the relations between Israeli employers and a Palestinian worker on Palestinian soil is the main factor in the lack of enforcement of Israeli standards on Palestinian workers (Korkus, 16/04/2007). The Oslo agreements added confusion by excluding the settlements from the interim period arrangements and by leaving zone (C) under complete Israeli control.

Other explanations can be given for the non-application of Israeli standards and guidelines. Some employers use a comparison with the nearby Palestinian territories, or even with other countries in the region to explain the work conditions of Palestinian workers (Korkus, 28/12/2008)! Good safety and health conditions at work, it should be noted, are a basic right stipulated by Israeli and international law. It applies within the territory of Israel and all territories under its effective jurisdiction. An employer's refusal to provide workers with protection and to improve the physical conditions in the work place is a legal offence (Abu Yusuf 28/04/2008). Why, then, do Israeli employers not comply with Israeli law?

The most important reason for the non-compliance is financial, but there is also the lack of government enforcement (Kav LaOved, 23/08/2008; Abu Yusuf 06/12/2008; Korkus, 28/12/2008), the indifference of workers and their lack of awareness of dangers in the workplace (Alinat, 16/09/2008b), carelessness concerning precaution measures (Abu Yusuf, 20/05/2008), and the lack of information concerning workers' rights and alternative work choices (Ginat, 17/09/2006; Abu Yusuf, 08/06/2008; Kav LaOved, 23/08/2008; Abu Yusuf 06/12/2008). The main obstacle, however, remains the fear of losing one's job and being unable to find another one (Ginat, 17/09/2006; Alinat, 12/03/2007; Kav LaOved, 11/01/2008; Amro, 23/09/2008). It should be noted that, in certain cases, Palestinian workers succeeded in uniting and organizing strikes and protests and looked for public support through awareness activities (Goldstein, 18/10/2007; Goldstein, 15/11/2007). Many important court decisions would not have been adopted if nobody had had the courage to stand up for their rights.

\section{Conclusion}

In 2007, the ISC ruled unanimously that Israeli labor laws applied equally to Israeli employers and their Palestinian West Bank workers (Kav LaOved, 23/08/2008). The ISC reversed the decision adopted by National Labor Court in 2003 and adopted a similar position to that taken by the Regional Labor Court in 1998 (Kav LaOved, 11/10/2007), which ruled that Israeli law, and not Jordanian law, 
also applies to Palestinians working in Israeli settlements on the West Bank. Since then, the number of claims by Palestinian workers employed in Israeli settlements of the West Bank has risen (Kav LaOved, 23/08/2008).

This petition was submitted by Kav LaOved, ${ }^{4}$ and two Palestinians working for Israeli employers in the West Bank, who claimed themselves discriminated against and economically disadvantaged by the non-application of Israeli labor law. In fact Israeli labor law is more attractive for Palestinian workers than Jordanian law in terms of the minimum wage, severance pay and various social benefits. In certain cases, it contains even better provisions than the Labor legislation endorsed by the PA and applied in the territories under its control. However, there are indications that, for Palestinian workers, Israeli settlements were transformed over time into a legal 'no man's land' where everything is possible and nothing forbidden (Korkus, 16/04/2007).

The Histadrut (General federation of Israeli Trade Unions) joined Kav LaOved and the workers when the case reached the National Labor Court (Kav LaOved, 11/10/2007), while the Israeli Attorney General, who got involved when the case was already underway, opposed such an approach (Yoaz, 11/10/2007), taking the side of the local council of Givat Ze'ev, and the Israeli companies in that settlement. The reasons for such positions vary. A narrow analysis might suggest that the financial cost is the only motive for rejecting the applicability of Israeli standards on all workers in Israeli settlements, including Palestinians who work there. A wider analysis might though end up by suggesting different and deeper reasons that go beyond financial and economic considerations.

The Palestinian Authority (PA) was reticent about taking action over the work of Palestinians inside Israeli settlements, considered illegal under international law, for lack of alternative work opportunities and the continuous deterioration of the Palestinian economy, which is, of course, highly dependent on Israel. The PA, consequently, did not, and for many reasons, could not adopt a formal position regarding the petition of Palestinian workers before the ISC requesting the extension of Israeli Labor law on Palestinians working in Israeli settlements. It was clear, however, that the PA was not ready to support such a request, deemed inappropriate since it might end by indirectly recognizing Israeli sovereignty over parts of Palestinian territory, occupied in 1967. The same political motivation was behind the initial reticence of the Palestinian General Federation of Trade Unions (PGFTU). ${ }^{5}$

The current author argues that the above position is based on a misunderstanding of the nature of the petition and of the objectives and public policies behind the ISC decision, the highest Israeli judicial authority. Asking for better and more favorable labor does not mean, by any means, sacrificing (Palestinian) national interests for the sake of (workers') private ones. A national court decision would not convert illegal settlements under international law into legal ones. A court decision means only what it can mean. It applies to the case and, sometimes, to similar ones (when the legal system is based on precedents).

A field researcher, interviewing a striking Palestinian worker in an Israeli settlement, reformulated the above dilemma into the following challenging question: "Isn't your demand to uphold Israeli labor laws actually a statement that this is Israel here?" "No, what we're saying is, if profits from our work go to Israel, the financing is Israeli, the customers are Israeli and the factory is adjacent to Israel wages and benefits should conform to Israeli standard[s]" (Goldstein, 18/10/2007).

\footnotetext{
${ }^{4}$ Kav LaOved is an Israeli non-profit non-governmental organization. Its objective is to protect the rights of disadvantaged workers employed in Israel and by Israelis in the Occupied Territories, including Palestinians, migrant workers, subcontracted workers and new immigrants. http://www.kavlaoved.org.il/about_n_eng.asp

${ }^{5}$ In later stages, the PGFTU realized that the number of Palestinian workers inside Israeli settlements in need of help is increasing. The PGFTU had held several joint activities and initiatives with Kav LaOved aiming at raising awareness for Palestinian workers and at collecting data concerning their work conditions. This proves that PGFTU is no more reluctant to request that decent work standards are applicable to Palestinian workers inside Israeli settlements (Kav LaOved, 23/08/2008).
} 
Granting equal rights without discrimination based on nationality is an obligation for all states, through customary and conventional international law. This obligation extends to all territories falling under the jurisdiction of a state and not only within the borders of recognized territory of a state. It is inconceivable, then, that we should re-interpret international humanitarian law (with regards to the need not to change the law of the territories under occupation) to mean the discrimination of local populations and the application of dual systems of law. Such a reinterpretation would lead to the system that was historically applied in several countries, i.e. "colonization," and/or "apartheid," and to the system that is currently applied in Israeli settlements in particular and the occupied Palestinian territory (oPt) in general.

The ISC stresses the importance of equality, which is not only a national value but also a universal one. As rightly put by Justice Salim Joubran: “The Labor Court's ruling implies that the only distinction between the Palestinian and Israeli workers is that the former are Palestinians, residents of the Palestinian Authority. This distinction on the basis of nationality is improper and tantamount to discrimination... applying a foreign law to Palestinian workers and the Israeli law to Israeli ones infringes on the Palestinians' basic rights and discriminates against them, although they all work together” (Yoaz, 11/10/2007).

In this sense, one can consider the ISC ruling a victory. A limited one, though. The struggle for equality and non-discrimination will be long, especially with the rule of a complicated system of law, used and manipulated by the occupier to carry out objectives that go beyond the law itself. The occupation policy, realized through a comprehensive system of law, had created institutions and structures that need much more than a court decision. They need state actions that dismantle structures, procedures and mechanisms of oppression and discrimination that were built through decades of occupation.

Some have even ended up by qualifying the kind of relationship that 'separates' Israelis or, more specifically, Israeli-Jews, from Palestinians or, more specifically, the oPt Palestinians, ${ }^{6}$ with the same adjectives given to the relationship that 'connected' the colonizer with the colonized. ${ }^{7}$ The objective of granting such qualification is not to accuse or to condemn but to analyze the peculiarity of the Israeli domination system (cf. Farsakh 2007). The abuse of rights to which Palestinians working in Israeli settlements are subjected is only one example of this multilayered system. In other words, the kind of relationship that connects the Palestinians working in the settlement and their Israeli employers goes beyond the simple employer-worker relationship, to embody the Israeli-Palestinian conflict as a whole (Alinat, 12/03/2007).

\footnotetext{
${ }^{6}$ I preferred to use 'Israeli-Jews' and 'oPt Palestinians' because there are almost a million Palestinian nationals who enjoy Israeli citizenship.

${ }^{7}$ John Dugard, former Special Rapporteur on the situation of human rights in the Palestinian territories occupied by Israel since 1967 stated authoritatively in the 59th Session of the General Assembly, Third Committee, Item 105 (c), NEW YORK, 28 October 2004 (available at: http://www.pchrgaza.org/Library/Dugard.pdf): “There are both similarities and differences between apartheid South Africa and the situation in the Palestine Occupied Territory (OPT). But one similarity is clear. Israel's conduct in the OPT poses the same kind of challenge to the credibility of international human rights that apartheid did in the 1970's and 1980's. There are gross, egregious and systematic violations of human rights and international humanitarian law in the OPT, committed not by undisciplined and uncontrolled militias but by one of the most disciplined and sophisticated armies in the modern world, directed by a stable and disciplined government." He even compared and linked the permit system Israel is applying over Palestinians to the "pass laws" of apartheid.
} 


\section{List of References}

Abu Yusuf, Raed, 06/12/2008. Factories in Nitzaney Hashalom: workers Exposed to daily health risks. Kav LaOved: http://www.kavlaoved.org.il/media-view_eng.asp?id=1921

Abu Yusuf, Raed, 08/06/2008. Barkan settlement industrial zone: a clear and present danger for Palestinian workers. Kav LaOved: http://www.kavlaoved.org.il/media-view_eng.asp?id=1708

Abu Yusuf, Raed, 20/05/2008. Work related accidents and occupational hazards in Israeli factories in the West Bank. Kav LaOved: http://www.kavlaoved.org.il/media-view_eng.asp?id=1670

Abu Yusuf, Raed, 28/04/2008. Sites of slow death: a review of two factories in the Israeli West Bank settlements. Kav LaOved: http://www.kavlaoved.org.il/media-view_eng.asp?id=1627

Alinat, Salwa, 03/01/2009. Palestinian Workers vs. labor contractors in West Bank settlements' Industrial zones. Kav LaOved: http://www.kavlaoved.org.il/media-view_eng.asp?id=2060

Alinat, Salwa, 06/12/2008. Palestinians refused work permits on security grounds: what's behind it? Kav LaOved: http://www.kavlaoved.org.il/media-view_eng.asp?id=2025

Alinat, Salwa, 16/09/2008a. Israeli company exploits Palestinian workers in the West Bank. Kav LaOved: http://www.kavlaoved.org.il/media-view_eng.asp?id=1913

Alinat, Salwa, 16/09/2008b. Report: poor work safety for Palestinian workers at Israeli West Bank settlements. Kav LaOved: http://www.kavlaoved.org.il/media-view_eng.asp?id=1912

Alinat, Salwa, 12/03/2007. Witout Fear: Palestinian workers in the settlements. Kav LaOved http://www.kavlaoved.org.il/media-view_eng.asp?id=601

Alinat, Salwa, and Kol Ha'ir, 10/11/2006. Work in hell: Op-ed piece on Palestinian economy and labour. http://www.kavlaoved.org.il/media-view_eng.asp?id=122

Amro, Arafat, 23/09/2008. Alei Zahav Industrial Zone: a real struggle for employment documents. Kav LaOved: http://www.kavlaoved.org.il/media-view_eng.asp?id=1920

Farsakh, Laila, 2007. The Political Economy of Israeli Occupation: what is Colonial about it? Department of Political Science, University of Massachusetts, Boston, Working Paper Series. http://www.pol-sci.umb.edu/papers/Farsakh_Pol_Ey_Occupation_2006.pdf

Ginat, Gitit, 17/09/2006. Dates of infamy. Haaretz: http://www.kavlaoved.org.il/mediaview_eng.asp?id=193

Goldstein, Tani, 15/11/2007. A strike in West Bank factory Sol-Or. Ynet (Nov 7, 2007). http://www.kavlaoved.org.il/media-view_eng.asp?id=1189 
Goldstein, Tani, 18/10/2007. Palestinian workers of Israeli owned "Yamit” West Bank factory go on strike. Ynet (Oct 11, 2007): http://www.kavlaoved.org.il/media-view_eng.asp?id=1147

Hass, Amira, 10/05/2007. The yearnings for a magnetic card. Haaretz (May 9, 2007). http://www.kavlaoved.org.il/media-view_eng.asp?id=744

Irin News, 07/09/2008. ISRAEL-OPT: Scheme to give Israelis "wet jobs" in construction in place of Palestinians (Aug 28, 2008). http://www.kavlaoved.org.il/media-view_eng.asp?id=1892

Kav LaOved, 07/09/2008. Precedent: Palestinian injured at work in a settlements recognized by Israeli National Insurance. http://www.kavlaoved.org.il/media-view_eng.asp?id=1889

Kav LaOved, 23/08/2008. Palestinian workers in West Bank Israeli settlements after the High Court of Justice Ruling. http://www.kavlaoved.org.il/media-view_eng.asp?id=1867

Kav LaOved, 06/04/2008. Abuse of Palestinian workers rights by authorites by: http://www.kavlaoved.org.il/media-view_eng.asp?id=1569

Kav LaOved, 11/01/2008. West Bank Palestinian workers employed in Israeli settlements: we'll fight for our rights under Israeli labour law. http://www.kavlaoved.org.il/media-view_eng.asp?id=1352

Kav LaOved, 03/12/2007. A workshop for Palestinians workers employed by Israelis in West Bank industrial zones. http://www.kavlaoved.org.il/media-view_eng.asp?id=1224

Kav LaOved, 11/10/2007. Precedent setting ruling: Israeli labour law applies to Palestinians employed by Israelis in Occupied Territories. http://www.kavlaoved.org.il/media-view_eng.asp?id=1123

Kav LaOved, 08/10/2007. Social Security to pay Palestinian worker employed in settlement. http://www.kavlaoved.org.il/media-view_eng.asp?id=1110

Kav LaOved, 02/07/2007. A court petition to reinstate Palestinian workers' council members in a "Nitsaney Shalom" Industrial Park factory. http://www.kavlaoved.org.il/mediaview_eng.asp?id=861

Kav LaOved, 19/05/2007. Palestinian construction worker seriously injured at construction site; Palestinian quarry worker dies (May 9, 2007): http://www.kavlaoved.org.il/mediaview_eng.asp?id=766

Kav LaOved, 09/05/2007. Petition: Israeli authorities in West Bank must provide a Palestinian with work permit or pay his subsistence. http://www.kavlaoved.org.il/media-view_eng.asp?id=741

Korkus, Simone, 28/12/2008. Child labour in Jewish settlements. Kav LaOved (MO, Dec. 11, 2008): http://www.kavlaoved.org.il/media-view_eng.asp?id=2049 
Korkus, Simone, 16/04/2007. Back to the Wall. http://www.kavlaoved.org.il/mediaview_eng.asp?id=667

Sinai, Ruth, 04/07/2007. Study: W. Bank laborers earn less than 50\% of minimum wage. Haaretz (July 4, 2007): http://www.kavlaoved.org.il/media-view_eng.asp?id=866

Yoaz, Yuval, 11/10/2007. High Court: Israeli labor laws to apply to Palestinians who work in settlements. http://www.kavlaoved.org.il/media-view_eng.asp?id=1126 